\title{
Effect of spatial arrangement on the production components and yield of sunflower ${ }^{1}$
}

\author{
Francisco Thiago Coelho Bezerra ${ }^{2 *}$, Alek Sandro Dutra ${ }^{3}$, João Bosco Pitombeira ${ }^{4}$
}

10.1590/0034-737X201663020013

\begin{abstract}
The sunflower plant is an oilseed crop that has aroused a great interest in the Brazilian and international scenery especillay because of the possibility of using its oil for biodiesel production. The objective of this study was to evaluate productivity and yield components of Embrapa 122 sunflower according to the spatial arrangement. Treatments were arranged in $4 \times 4$ factorial arrangement, which are the four spacings between rows $(0.30 ; 0.50 ; 0.70$ and $0.90 \mathrm{~m})$ and four sowing densities $\left(30,000 ; 45,000 ; 60,000\right.$ and 75,000 plants ha $\left.^{-1}\right)$. The experiment was carried out in a complete randomized block design with four replications. The experiments were conducted in the experimental area of the Plant Science Department in Fortaleza, State of Ceará-Brazil and on the Curu Vale Experimental Farm in Pentecoste, State of CearáBrazil. Productivity and the following production components were analyzed in the end of the crop cycle: harvested capitula, capitulum diameter, capitulum mass, achene mass per capitulum, mass of 100 achenes, achenes per capitulum, harvest index and oil content in the achenes. The experiments were analyzed jointly in relation to the cropping area and the data submitted to analysis of variance and quantitative factors tested by polynomial regression. The variables, spacing, density and cropping area did not interact with these variables and the spatial arrangement of the plants affected only the components. The cropping area influences the productive behavior of sunflower Embrapa 122. The spatial arrangement of the plants of sunflower of variety Embrapa 122 influences yield components but does not affect productivity.
\end{abstract}

Key words: biodiesel, density, Helianthus anпииs L., spacing.

\section{RESUMO}

\section{Efeito do arrano especial nos componentes de produção e produtividade de girasol}

O girassol é uma oleaginosa que vem despertando maior interesse nos cenários nacional e internacional, por causa, principalmente, da possibilidade da utilização do óleo na fabricação de biodiesel. O objetivo deste trabalho foi avaliar componentes de rendimento e de produtividade do girassol var. Embrapa 122, em função do arranjo espacial. Os tratamentos foram arranjados no esquema fatorial $4 \times 4$, referentes a quatro espaçamentos entre linhas $(0,30 ; 0,50 ; 0,70 \mathrm{e}$; $0,90 \mathrm{~m})$ e quatro densidades de semeadura $\left(30.000 ; 45.000 ; 60.000 \mathrm{e} ; 75.000\right.$ plantas ha $\left.^{-1}\right)$, sendo organizados no delineamento de blocos casualizados, com quatro repetições. Os experimentos foram desenvolvidos na Área Experimental do Departamento de Fitotecnia, em Fortaleza, CE-Brasil, e na Fazenda Experimental Vale do Curu, em Pentecoste, CE-Brasil. Ao final do ciclo da cultura, avaliaram-se a produtividade e os seguintes componentes de produção: capítulos colhidos, diâmetro do capítulo, massa do capítulo, massa de aquênios por capítulo, massa de 100 aquênios, aquênios por capítulo, índice de colheita e teor de óleo nos aquênios. Os experimentos foram analisados de forma conjunta em relação ao local

\footnotetext{
Submitted on 09/08/2014 and approved on 10/19/2015.

'Part of the first author's master's degree thesis. Funding Source: programa de Pós-Graduação em Agronomia/Fitotecnia da UFC.

Universidade Federal da Paraíba, Departamento de Fitotecnia e Ciências Ambientais, Programa de Pós-Graduação em Agronomia, Areia, Paraíba, Brasil. bezerra_ftc@yahoo.com.br

${ }^{3}$ Universidade Federal do Ceará, Centro de Ciências Agrárias, Departamento de Fitotecnia, Fortaleza, Ceará, Brasil. alekdutra@ufc.br

Universidade Federal do Ceará, Centro de Ciências Agrárias, Departamento de Fitotecnia, Fortaleza, Ceará, Brasil. pitomba@cca.ufc

Corresponding Author: bezerra_ftc@yahoo.com.br
} 
de cultivo, sendo os dados submetidos à análise de variância e os fatores quantitativos testados por meio de regressão polinomial. Os fatores espaçamento, densidade e local de cultivo não interagem sobre as variáveis estudadas e o arranjo espacial das plantas afetou apenas os componentes de produção. O local de cultivo influencia o comportamento produtivo de girassol var. Embrapa 122. O arranjo espacial das plantas de girassol var. Embrapa 122 influencia os componentes de produção, mas não afeta a produtividade.

Palavras-chave: Helianthus annuиs L., biodiesel, espaçamento, densidade.

\section{INTRODUCTION}

The sunflower crop (Helianthus annuus L.) has been arousing increasing interest on the Brazilian scene thanks to the quality of the oil for food purposes and to the use of its by-products for diets for animals, and for adapting to grain cultivation systems (Porto et al., 2007; Backes et al., 2008) and especially because of the possibility of using the oil in biodiesel manufacturing (Yokomizo, 2003).

In Brazil, the sunflower cropped area and crop production have increased. Estimates for the crop in the Brazilian harvest of 2013/2014 showed cropped area and production of 145,700 ha and 232,700 tons, respectively, with an average yield of $1,597 \mathrm{~kg} \mathrm{ha}^{-1}$. The Brazilian Central-west region is the leading producing region, especially the state of Mato Grasso, while in the northeast region, the production is concentrated in the states of Rio Grande do Norte, Ceará and Bahia (Conab, 2015).

According to Leite et al. (2007), sunflower adapts to different soil and climatic conditions and can be grown from the state of Rio Grande do Sul to Roraima, but several factors affect the performance of crop, among them, genotype, adequate management of soil fertility and environmental factors such as uniform distribution of water throughout the crop cycle. This crop presents genetic potential for achieving high yields provided that good varieties are selected and an appropriate management is provided.

In general, the spatial arrangement of the crop obtained by the combination of spacing between rows and plant spacing within the row (sowing density) affects yield components and productivity. The study of plant arrangement allows to defining the best arrangement in the area so that to reduce competition for environmental resources, in addition of searching for a greater efficiency in weed control and to adequate cropping using the available machinery (Silva et al., 1995). Rizzardi \& Silva (1993) found that short-cycle and small size sunflower cultivars present greater potential for oil yield under higher densities and long cycle and medium and high-sized cultivars express higher yields of oil and grains under lower density levels.
Environmental conditions during cultivation also affect the sunflower productivity. According to Aguirrezábel et al. (2001), yield components are defined at different growth stages and environmental conditions, which change over the crop cycle, affect yield by means of distinct components. However, each environmental factor affects a component at different intensity from the other, and compensation among the influences from the different production components may occur.

Therefore, the objective of this study was to evaluate the effects of spatial arrangements of plants on yield and production components of the sunflower variety Embrapa 122 in two cultivations sites in the state of Ceará-Brazil.

\section{MATERIAL AND METHODS}

Two experiments were carried out in an experimental area. One in the Plant Science Department (PSD) at Pici Campus, in Fortaleza, state of Ceará-Brazil ( $3^{\circ} 44^{\prime} \mathrm{S}$ and $38^{\circ}$ $33^{\prime} \mathrm{W}$, at $19.5 \mathrm{~m}$ above sea level). The another in the Vale do Curu Experimental Farm (VCEF) ( $3^{\circ} 47^{\prime} \mathrm{S}$ and $39^{\circ} 16^{\prime} \mathrm{W}$, at $45 \mathrm{~m}$ above sea level) in Pentecoste, state of CearáBrazil. Both belonging to Ceará Federal University (UFC).

The sunflower was manually sowed on March 15, 2012 in Pentecoste. The soil area was a Planosol at 0-20 cm depth profile with the following chemical characteristics. As pH in water (1:2.5) of 6.4; electrical conductivity of the saturation extract of $0.11 \mathrm{dS} \mathrm{m}{ }^{-1} ; \mathrm{Ca}^{2+}, \mathrm{Mg}^{2+}, \mathrm{K}^{+}, \mathrm{Al}^{3+}, \mathrm{Na}^{+}$, $\left(\mathrm{H}^{+}+\mathrm{Al}^{3+}\right)$, BS and CEC of 0.90; $1.00 ; 0.09 ; 0.05 ; 0.05 ; 0.33$; 2.04 and 2.37, respectively; $\mathrm{P}$ of $4 \mathrm{mg} \mathrm{kg}^{-1}$ and organic matter of $6.4 \mathrm{~g} \mathrm{~kg}^{-1}$. At Fortaleza, sowing was carried out on April 15, 2012. The soil area was a Red-Yellow Argisol with the following chemical properties at the layer $0-20 \mathrm{~cm}$ depth profile. As $\mathrm{pH}$ in water (1:2.5) of 5.2; electrical conductivity of the saturation extract of $0.17 \mathrm{dS} \mathrm{m}{ }^{-1} ; \mathrm{Ca}^{2+}$, $\mathrm{Mg}^{2+}, \mathrm{K}^{+}, \mathrm{Al}^{3+}, \mathrm{Na}^{+},\left(\mathrm{H}^{+}+\mathrm{Al}^{3+}\right)$; $\mathrm{BS}$ and CEC of $0.80 ; 1.40$; $0.13 ; 0.35 ; 0.04 ; 0.99 ; 2.37$ and 3.36 , respectively; $\mathrm{P}$ of $4 \mathrm{mg}$ $\mathrm{kg}^{-1}$; and organic matter of $7.6 \mathrm{~g} \mathrm{~kg}^{-1}$.

Weeds were controlled by hand weeding. At Pentecoste, the experiment was conducted in dry farming whereas at AEDF in Fortaleza, additional irrigations were used. Regarding climate classification, according to 
Köppen, the city of Fortaleza is inserted in the Aw' rainy tropical climate, while in Pentecoste, the BSw'h type, that is, dry semi-arid climate group predominates with a small wet season (Aguiar et al., 2004a, b). The weather data of the average air temperature and rainfall in the experimental areas during the experiment can be seen in Figure 1.

Fertilization consisted of the application of urea (45\% nitrogen), simple superphosphate $\left(20 \%\right.$ of $\left.\mathrm{P}_{2} \mathrm{O}_{5}\right)$ and potassium chloride $\left(60 \%\right.$ of $\left.\mathrm{K}_{2} \mathrm{O}\right)$, according to the recommendation of $50: 50: 40 \mathrm{~kg} \mathrm{ha}^{-1}$, corresponding to $\mathrm{N}$, $\mathrm{P}_{2} \mathrm{O}_{5}$ and $\mathrm{K}_{2} \mathrm{O}$, respectively (EMPARN, 2009). The fertilization with phosphorus and potassium was carried out at the foundation. However, nitrogen was applied in splits, with one-third applied in the foundation of fertilization and the rest in top-dressing, 35 days after sowing, along with fertilizer at the dose of $2 \mathrm{~kg} \mathrm{ha}^{-1}$ of boron, in which boric acid ( $17 \%$ B) was the source.

The early cycle Embrapa 122 sunflower variety with short size and high productivity and drought tolerant (Amorim et al., 2008) was used in the experiment. Sixteen treatments were evaluated. Those treatments were arranged in a $4 \times 4$ factor design, with four spacings between rows $(0.30,0.50,0.70$ and $0.90 \mathrm{~m})$ and four sowing densities (30,000; 45,000; 60,000 and 75,000 plants ha $\left.{ }^{-1}\right)$, distributed in four randomized blocks. The experimental unit consisted of a plot with six meters in length and four rows, with the floor area of the two central lines, excluding the plants in the edges of these rows.

At the end of the crop cycle, on day 98 after sowing, harvested capitula (HC) were quantified in a sample with four capitula per plot. The capitulum diameter (CD) was determined by the mean between two perpendicular measures among each other using a caliper, and capitulum mass (CM) and mass of achenes per capitulum (MAC) was determined by measuring fresh mass on a precision scale. It was also determined the mass of 100 achenes (M100A) from a sample of 100 achenes per plot; achenes mass per capitulum (AC), estimated from the average mass of achenes per capitulum and the mass of 100 achenes and yield (PROD), corrected to $12 \%$ moisture.

The content of oil was determined in the achenes of the sunflower, obtained by the method of heated solvent (hexane) in a TE-044 ${ }^{\circledR}$ (TECNAL) fat determiner, using 5-g blended sample per plot (Zenebon et al. , 2008). In addition to the aforementioned variables, the harvest index (HI) was determined by means of the relationship between the production of achenes and production of total plant mass above ground (Larcher, 2006).

The results of each experimental area were submitted to analysis of variance and then evaluated for homogeneity of errors by the ratio between the largest and the smallest error. Once the homogeneity of errors was set, the joint analysis was carried out by analysis of variance and polynomial regression using the $F$ test $(p \leq 0.05)$ to verify the significance of the factors as well as their interactions and data adjustments for the regression equations.

\section{RESULTS AND DISCUSSION}

For the variable harvested capitula, the highest average capitulum production was found in Fortaleza, estimated at 41,825 capitula per hectare, whereas in Pentecoste, it was obtained the production of 35,039 capitula per hectare. In Fortaleza, the highest yield in relation to the spacing was 45,591 capitula per hectare, spaced by $0.63 \mathrm{~m}$ between rows (Figure 2A) and, in relation to the sowing density, it is estimated an increase of 787 capitula per hectare, for every increase of 1,000 plants, obtaining 59,392 capitula per hectare at a density of 75,000 plants (Figure 2B). In Pentecoste, the estimated maximum yield of 27,894 capitula per hectare was obtained by combining spacing between rows of 0.3

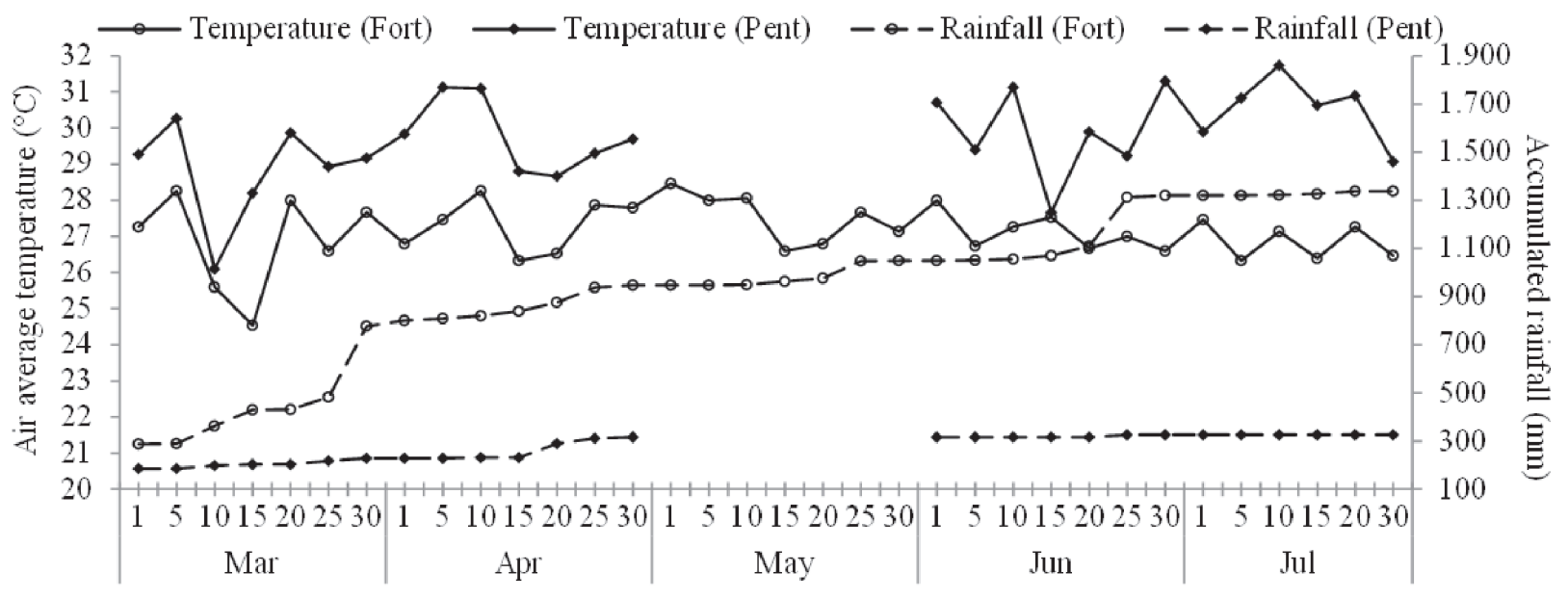

Figure 1: Weather data of air average temperature (-) and accumulated rainfall (----) at Pici Campus (O), in Fortaleza and at Vale do Curu Experimental Farm $(\diamond)$, in Pentecoste. 
$\mathrm{m}$ with the sowing density of 71,519 plants per hectare (Figure 2C).

According to Aguirrezábel et al. (2001) in a certain area, the number of capitula is the result from the number of plants able to develop an inflorescence. Vogt et al. (2012) found a ratio of capitula per plant ranging from 0.57 to 0.97 , with the variety EMBRAPA 122, a ratio of 0.89 . While Backes et al. (2008) obtained for the same variety, a variation in the proportion of capitula per plant from 0.94 to 0.56 , only when sowing was postponed from late January to early February, in the municipality of Papanduva, SC. The environmental conditions affect in different manners the production components, which are defined at different phonological stages, but the reduction of a given component can be compensated by the increase in the influence by another (Aguirrezábel et al., 2001). That is, the reduction in the number of capitula may result in larger diameter of the capitulum and an increase in the number, or in the mass of achenes per capitulum.

In relation to the diameter of the harvested capitula, it was observed that in Fortaleza, they presented an average of $80.08 \mathrm{~mm}$ in diameter, larger than the ones harvested in Pentecoste, which were $68.82 \mathrm{~mm}$, in average. For the spacing between rows, in the crop in Pentecoste, it is estimated that for every increase of $0.1 \mathrm{~m}$, there is an increase of $16.46 \mathrm{~mm}$ in the diameter of capitula, resulting in a maximum of $73.75 \mathrm{~mm}$, for the spacing of $0.9 \mathrm{~m}$ (Figure 3A). Regarding the sowing density for plants grown in
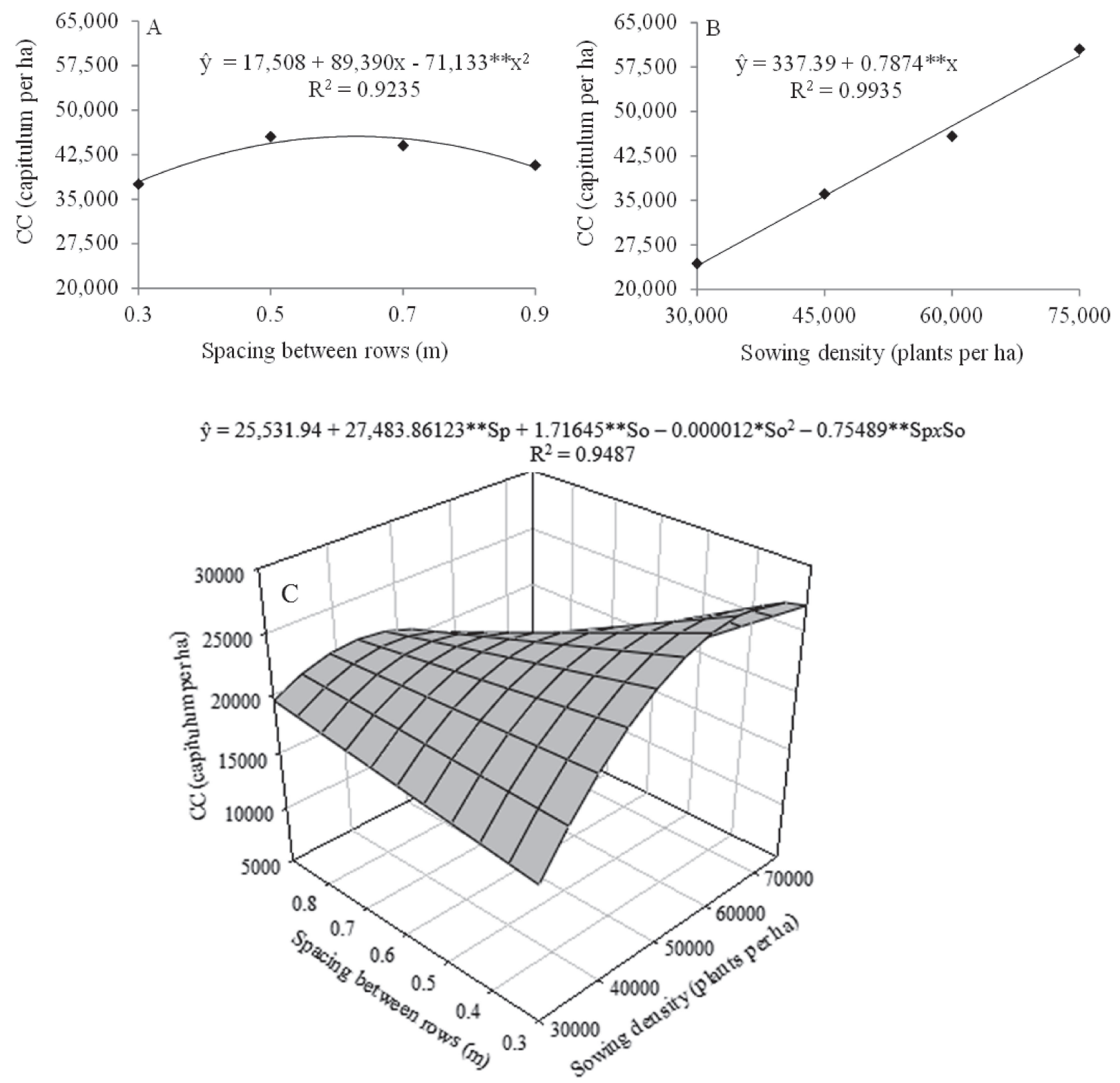

* e **: significant at 5 and $1 \%$, respectively by the $\mathrm{F}$ test.

Figure 2: Heads harvested from sunflower variety Embrapa 122 in function of spacing between rows (A) and in function of sowing density (B), in the Experimental Area of the Plant Science Department in Fortaleza, state of Ceará, and in function of the interaction between spacing between rows and sowing density (C) on Vale do Curu Experimental Farm in Pentecoste. 
Fortaleza, it is estimated a decrease of $18 \%$ of the diameter of the capitula when the population is increased from 30,000 to 64,286 plants per hectare, followed by a slight increase up to the population of 75,000 plants, while in VCEF in Pentecoste, the increase in population reduced the diameter of capitula by $0.3 \mathrm{~mm}$ for every increase of 1,000 plants per hectare (Figure 3B), obtaining, for each area, the respective maximus of $91.28 \mathrm{~mm}$ and $73.89 \mathrm{~mm}$ when the crop was established at a density of 30,000 plants per hectare.

When evaluating genotypes of sunflower grown at spacings of 0.4 and $0.8 \mathrm{~m}$ between rows, Silva et al. (2009a) and Martin et al. (2012) found no differences in the diameter of the capitulum. However, Backes et al. (2008), in the municipality of Papanduva, state of Santa Catarina, observed in Embrapa 122 sunflower variety, a variation of the diameter of capitula from 16.67 to $19.91 \mathrm{~cm}$, only when sowing was postponed from late January to early February, while Silva et al. (2011) observed an increase of $15.3 \%$ of this variable when irrigation depth was increased from 89 $\mathrm{mm}$ to $534 \mathrm{~mm}$. This approach emphasizes that the variable diameter of capitula is sensitive to environmental variations of abiotic and biotic nature. Among the abiotic variations, meteorological factors can be cited, and among biotic variations, intraspecific competition, according to which the reduction in spacing between rows or the increase in sowing density resulted in decreases of the diameter of the capitula of sunflower plants.

The average values of capitulum fresh matter mass and achenes mass per capitulum in Fortaleza, were 35.10 and $24.31 \mathrm{~g}$, respectively, which were higher than those obtained in VCEF in Pentecoste, which presented the averages of 20.64 and $12.98 \mathrm{~g}$, respectively. For the spacing between rows, it was observed in Pentecoste, an increase of $10.72 \mathrm{~g}$ per capitulum for the increase of $0.1 \mathrm{~m}$ in spacing with a maximum of $23.86 \mathrm{~g}$ in the spacing of $0.9 \mathrm{~m}$ (Figure
4A). In function of the sowing density, in Fortaleza, it was estimated a decrease of $34 \%$ when increasing the population from 30,000 to 64,286 plants per hectare. By the other hand in Pentecoste, capitulum fresh mass decreased when population density increased. The estimated decrease was of $0.2 \mathrm{~g}$ per capitulum for an increase of 1,000 plants per hectare (Figure 4B). In each area, when the crop was established at a density of 30,000 plants per hectare the maximums of $48.19 \mathrm{~g}$ per capitulum in Fortaleza and $27.70 \mathrm{~g}$ per capitulum in Pentecoste were attained.

For data of mass of achenes per capitulum in function of sowing density, in Fortaleza, it was estimated a reduction from $33.89 \mathrm{~g}$ to $21.44 \mathrm{~g}$ of achenes per capitulum, a decrease of $37 \%$ when population increased from 30,000 to 63,636 plants per hectare. In Pentecoste, this decrease was linear, following an estimated rate of $0.2 \mathrm{mg}$ of achenes per capitulum, for each unitary increase in density (Figure 4C). The reduction of fresh mass of the capitula caused by the increase in the sowing density resulted from a higher intraspecific competition for resources from the environment, such as light, nutrients and water, affecting the mass of capitulum achenes, variables with high correlation (0.9876).

Orlando (2008) found no difference in the dry mass of the capitula in MG2 sunflowers hybrid at the population densities of 27,000 and 51,000 plants per hectare, and neither did the author found effect of spacing, which ranged from 0.45 to $0.90 \mathrm{~m}$. For mass of achenes per capitulum, the author observed a reduction when the population density increased from 27,000 to 51,000 plants per hectare, dropping from $69.27 \mathrm{~g}$ to $28.48 \mathrm{~g}$, representing a loss of $58.9 \%$ of dry matter, while the variation of the spacing between rows from $0.45 \mathrm{~m}$ to $0.90 \mathrm{~m}$ did not affect this variable. Silva \& Nepomuceno (1991) obtained similar responses to those above mentioned and observed a reduction in the mass of
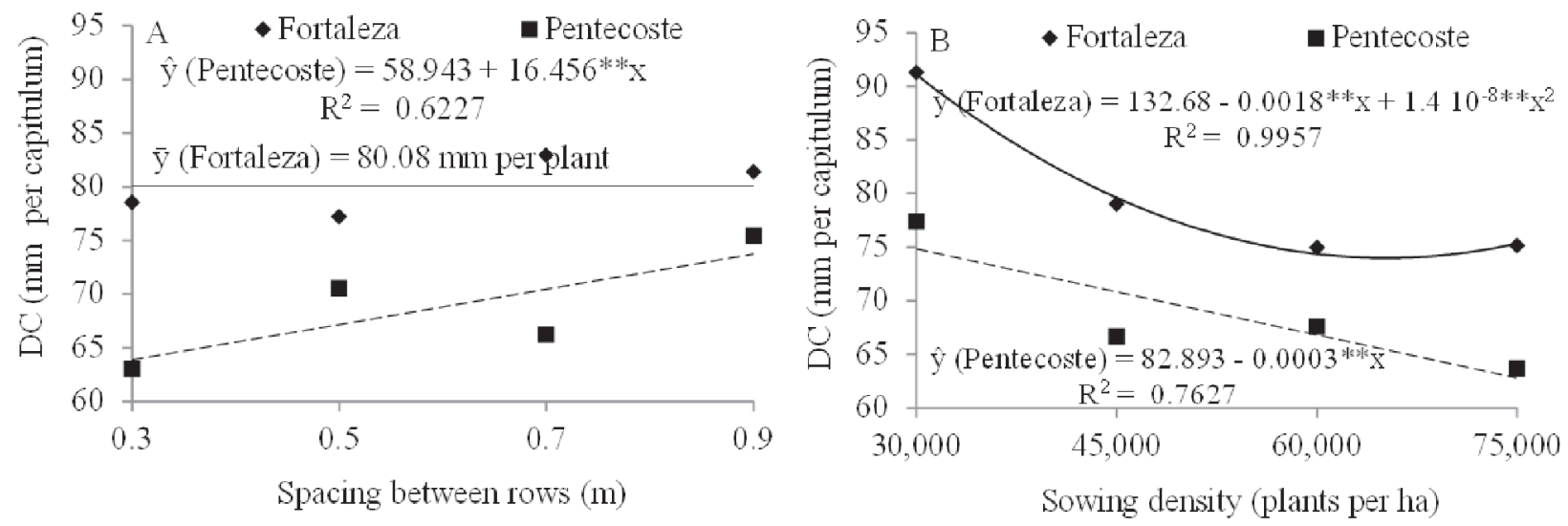

* e **: significant at 5 and $1 \%$, respectively by the test $\mathrm{F}$.

Figure 3: Diameter of achenes of sunflower variety Embrapa 122 in function of spacing between rows (A) and in function of sowing density (B) in the Experimental Area of the Plant Science Department in Fortaleza, state of Ceará ( $\bullet)$, and on Vale do Curu Farm, in Pentecoste (ם).

Rev. Ceres, Viçosa, v. 63, n.2, p. 214-222, mar/abr, 2016 
achenes per capitulum as plant density increased. They did not find effect from spacing between rows, however.

The highest average of achenes per capitula and 100 achene mass were achieved in Fortaleza, 210 achenes per capitulum and $11.74 \mathrm{~g}$ per 100 achenes. In Pentecoste, 174 achenes per capitulum and $7.34 \mathrm{~g}$ per 100 achenes were obtained, in average. The number of achenes per capitulum in relation to the spacing at VCEF in Pentecoste, had a linear increase of 96 achenes per capitulum for every increase of $0.1 \mathrm{~m}$ in spacing between rows, with a maximum
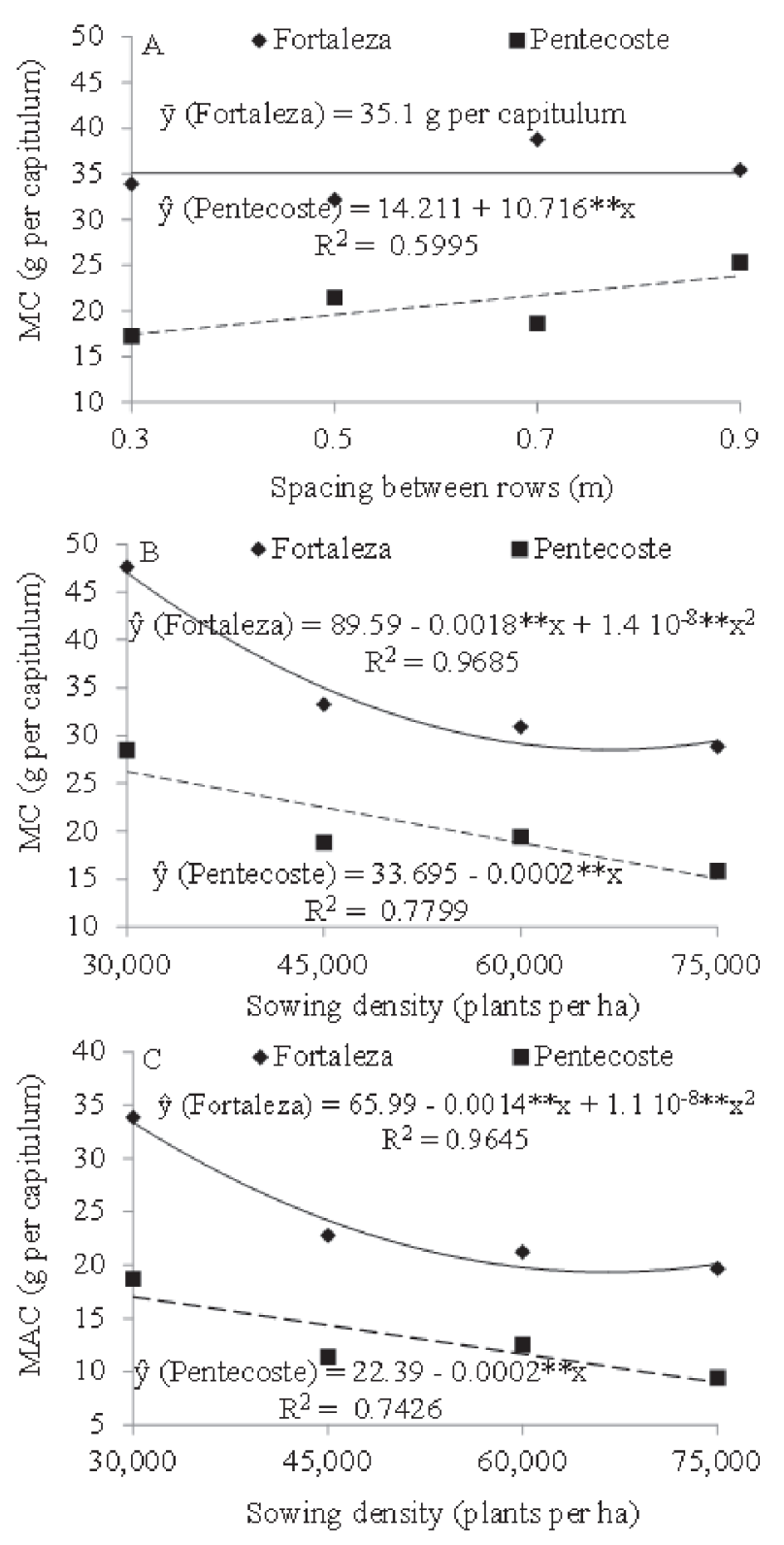

* e **: significant at 5 and $1 \%$, respectively by the $\mathrm{F}$ test.

Figure 4: Fresh mass of capitula of sunflower variety Embrapa 122 in function of spacing between rows (A) and in function of sowing density (B) and fresh mass of achenes in function of sowing density (C) in the Experimental Area in the Plant Science Department in Fortaleza $(\diamond)$, and on Vale do Curu Farm, in Pentecoste (ם). of 203 achenes per capitulum when the plants were grown in the 0.9-m spacing (Figure 5A). The number of achenes per capitulum in relation to sowing density in Pentecoste had a decrease of 1.9 achenes per capitulum for every increase in the population of 1,000 plants per hectare, with a maximum of 216 achenes in the density of 30,000 plants per hectare (Figure 5).

According to Rizzardi \& Silva (1993), the number of achenes per capitulum is the main determinant of the differential response of cultivars in relation to grain yield when submitted to high density of plants. These authors observed a reduction of this variable, by increasing population density. Moreover, Silva \& Nepomuceno (1991) observed a reduction in the number of achenes per capitulum as density was increased, but they did not obtain the effect of spacing between rows, while Silva et al. (2009 a, b) when evaluating sunflower genotypes observed reduction in the number of achenes per capitulum by increasing the spacing between rows.

For the variable mass 100 achenes, in Fortaleza, the maximum is estimated at $15.9 \mathrm{~g}$, obtained from the combination of the population of 30,000 plants per hectare and the spacing of $0.30 \mathrm{~m}$ between rows (Figure 5C). It is observed that the increase in intraspecific competition caused by reduction in the spacing between rows or within the row (density) of sowing results in loss of both the number and the mass of the achenes in sunflower plants.

Among the factors that interfere with the mass of achenes, it can be cited the growing season as noted by Backes et al. (2008) by reducing the mass of 100 achenes from $7.62 \mathrm{~g}$ to $6.90 \mathrm{~g}$, when sowing was postponed from late January to early February in 2007, in the municipality of Papanduva, state of Santa Catarina. However, Silva et al. (2009b) found an increase in mass of 1,000 achenes by increasing the spacing between rows from 0.4 to $0.5 \mathrm{~m}$, while Silva et al. (2009 a), when altered the spacing from 0.4 to $0.8 \mathrm{~m}$, found no differences. Rizzardi \& Silva (1993) observed a decrease as sowing density increased and Silva et al. (2011), found an increase in that variable, when variety Embrapa 122 was irrigated.

The average yield of achenes in Fortaleza was 1,516.57 $\mathrm{kg} \mathrm{ha}^{-1}$, which is higher than that obtained in Pentecoste, which was $702.64 \mathrm{~kg} \mathrm{ha}^{-1}$. Among the factors studied, it can be observed that the growing site was crucial in the productivity of achenes, where the irregularity and the difference in rainfall were the key factors (Figure 1) among the environmental factors because the crop yield is directly related to the availability of water in the soil (Santos et al., 2002). In relative terms, the loss of productivity in Pentecoste, compared with the one in Fortaleza was $53.67 \%$.

Drought tolerance depends on the species and within the same species, on the variety and on the plant development stage. Therefore, sowing at times that provide 
better use of favorable weather conditions should be preferred. Backes et al. (2008) observed a reduction in productivity from 1,190 to $460 \mathrm{~kg} \mathrm{ha}^{-1}$ with the genotype of sunflower Embrapa 122, when sowing was altered from late January to early February in 2007 in the municipality of Papanduva, state of Santa Catarina.

For plant arrangement, Braz \& Rossetto (2010) found no differences on productivity of sunflower grown with populations of 45,000 and 75,000 plants ha $^{-1}$, producing around $1,260 \mathrm{~kg} \mathrm{ha}^{-1}$. Plasticity regarded to variation on spatial arrangement varies according to species and variety. Soybean stands out among the crops with high phenotypic plasticity. This plant changes its production components in function of the available space, which does not affect productivity (Garcia et al., 2007; Mauad et al., 2010).

The highest harvest index was obtained in Fortaleza, with an average value of $44.49 \%$, while in Pentecoste, this value was only $34.23 \%$. According to Larcher (2006), the harvest index for cultivated seed producing plants is between 30 and 60\%. Braz \& Rossetto (2009) observed for this index, the average value of $40 \%$ for population densities of 45,000 and 75,000 plants ha ${ }^{-1}$ of Embrapa 122 variety sunflower, which did not differ, while Melo et al. (2004), when studying genotypes of sunflower found that, on average, $54.86 \%$ of the production of the aerial part dry matter is assigned to formation of capitulum.
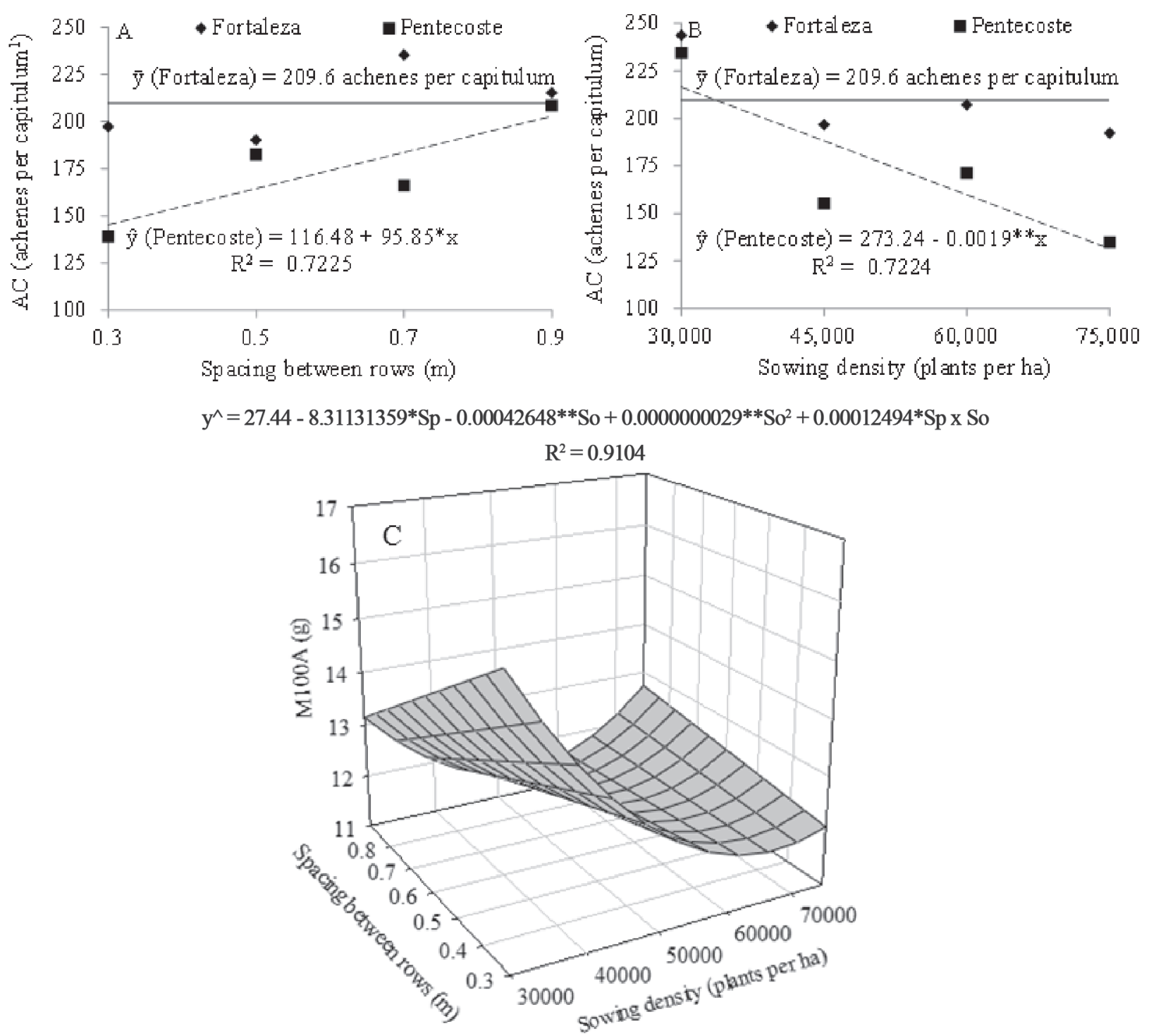

* e **: significant at 5 and $1 \%$, respectively by the $\mathrm{F}$ test.

Figure 5: Achenes per head of sunflower capitula of variety Embrapa 122 grown according to the spacing between rows(A) and sowing density (B) in the Experimental Area in the Plant Science Department in Fortaleza, state of Ceará ( $\bullet$ ) and on Vale do Curu Farm in Pentecoste, state of Ceará ( $\square)$, and mass of 100 achenes (C) according to the interaction between spacing between rows and sowing density in the Experimental Area at the Plant Science Department in Fortaleza. 
For the achene oil content, the average content of 46.39\% was observed in Fortaleza, a value higher than the one obtained in Pentecoste, which was $35 \%$, reflecting a reduction of $24.55 \%$. This variation between the cultivation sites becomes more significant when oil yield is evaluated. In Fortaleza, $703.54 \mathrm{~kg}$ per hectare was obtained and in Pentecoste, $245.92 \mathrm{~kg}$ per hectare was obtained, reflecting a loss of $65 \%$ of oil yield, affecting the profitability of the crop assigned for biodiesel production.

When evaluating genotypes of sunflower, Amorim et al. (2008) observed that the content of achenes oil ranged from 33.69 to $44.72 \%$, where an average content of $40.57 \%$ was obtained for the variety EMBRAPA 122. However, Rizzardi \& Silva (1993) observed an increase in the achene oil content in function of sowing density only in one of the evaluated genotypes, and Silva \& Nepomuceno (1991) also observed this trend as sowing density increased but they did not observe effect of spacing between rows. With the sunflower variety Embrapa 122, Braz \& Rossetto (2010) also observed an increase in oil content as sowing density increased, while Silva et al. (2011), with this same variety observed increases in oil content when irrigating the crop, estimated at 35.1 and $45.2 \%$, when using irrigation depths of 89 and $534 \mathrm{~mm}$, respectively. The oil content of sunflower achenes varies according to the genotype, water availability and the spatial arrangement of plants.

\section{CONCLUSIONS}

The factors spacing between rows, sowing density and cultivation site does not interact with the production components of the sunflower variety Embrapa 122.

The spatial arrangements that provide greater intraspecific competition decrease components of production however, they do not affect yield of achenes of variety Embrapa 122.

Production components and yield of sunflower plants variety Embrapa 122 are influenced by the soil and climatic conditions.

\section{REFERENCES}

Aguiar MJN, Viana TVA, Aguiar JV, Crisóstomo Júnior RR, Aquino FC \& Barreto Júnior JHC (2004a) Dados climatológicos: estação de Fortaleza, 2003. Fortaleza, Embrapa Agroindústria Tropical. 19p. (Documentos, 86).

Aguirrezábel LAN, Orioli GA, Hernández LF, Pereyra VR \& Miráve JP (2001) Girassol: aspectos fisiológicos que determinan el rendimiento. Buenos Aires, Unidad Integrada Balcarce. 111p.

Amorim EP, Ramos NP, Ungaro MRG \& Kihl TAM (2008) Correlações e análise de trilha em girassol. Bragantia, 67:307-316.

Backes RL, Souza AM, Balbinot Junior AA, Gallotti GJM \& Bavaresco A (2008) Desempenho de cultivares de girassol em duas épocas de plantio de safrinha no planalto norte Catarinense. Scientia Agraria, 9:41-48.
Braz MRS \& Rossetto CAV (2010) Acúmulo de nutrientes e rendimento de óleo em plantas de girassol influenciados pelo vigor dos aquênios e pela densidade de semeadura. Semina: Ciências Agrárias, 31:1193-1204.

Braz MRS \& Rossetto CAV (2009) Crescimento de plantas de girassol em função do vigor de aquênios e da densidade de semeadura. Ciência Rural, 39:1989-1996.

CONAB (2015) Acompanhamento da safra brasileira: grãos, decimo levantamento, julho de 2015. Brasília, CONAB. 108p.

EMPARN - Empresa de Pesquisa Agropecuária do Rio Grande do Norte (2009) Recomendações técnicas para o cultivo do girassol. Natal, EMPARN. 68p. (Sistema de Produção, 1).

Garcia A, Pípolo AE, Lopes ION \& Portugal FAP (2007) Instalação da lavoura de soja: época, cultivares, espaçamento e população de plantas. Londrina, Embrapa-CNPSo. 12p. (Circular Técnica, 51).

Larcher W (2006) Ecofisiologia Vegetal. São Carlos, Rima. 550p.

Leite RMVBC, Castro C, Brighenti AM, Oliveira FA, Carvalho CGP \& Oliveira ACB (2007) Indicações para o cultivo de girassol nos Estados do Rio Grande do Sul, Paraná, Mato Grosso do Sul, Mato Grosso, Goiás e Roraima. Londrina, Embrapa-CNPSo. 4p. (Comunicado Técnico, 78).

Martin TN, Pavinato PS, Lorentz LH, Zielinski RP \& Refatti R (2012) Spatial distribution of sunflower cultivars and the relationship between growth features. Revista Ciência Agronômica, 43:338-345.

Mauad M, Silva TLB, Almeida Neto AI \& Abreu VG (2010) Influência da densidade de semeadura sobre características agronômicas na cultura da soja. Revista Agrarian, 3:175-181.

Melo R, Nörnberg JL \& Rocha MG (2004) Potencial produtivo e qualitativo de híbridos de milho, sorgo e girassol para ensilagem. Revista Brasileira de Agrociência, 10:87-95.

Orlando AF (2008) Cultivo de girassol na "safrinha" no oeste do Paraná: efeitos do espaçamento entre linhas e populações de plantas. Dissertação de Mestrado. Universidade Estadual do Oeste do Paraná, Marechal Cândido Rondon. 40p.

Porto WS, Carvalho CGP \& Pinto RJB (2007) Adaptabilidade e estabilidade como critérios para seleção de genótipos de girassol. Pesquisa Agropecuária Brasileira, 42:49-499.

Rizzardi MA \& Silva PRF (1993) Resposta de cultivares de girassol à densidade de plantio em duas épocas de semeadura: I rendimento de grãos e óleo e componentes de rendimento. Pesquisa Agropecuária Brasileira, 28:675-687.

Santos AC, Andrade AP, Lima JRS, Silva IF \& Cavalcante VR (2002) Variabilidade temporal da precipitação pluviométrica: nível de nitrogênio no solo e produtividade de cultivares de girassol. Ciência Rural, 32:757-764.

Silva AG, Moraes EB, Pires R, Carvalho CGP \& Oliveira ACB (2009a) Efeitos do espaçamento entre linhas nos caracteres agronômicos de três híbridos de girassol cultivados na safrinha. Pesquisa Agropecuária Tropical, 39:105-110.

Silva AG, Pires R, Morães EB, Oliveira ACB \& Carvalho CGP (2009b) Desempenho de híbridos de girassol em espaçamentos reduzidos. Semina: Ciências Agrárias, 30:31-38.

Silva ARA, Bezerra FML, Sousa CCM, Pereira Filho JV \& Freitas AS (2011) Desempenho de cultivares de girassol sob diferentes lâminas de irrigação no Vale do Curu, CE. Revista Ciência Agronômica, 42:57-64.

Silva PRF \& Nepomuceno AL (1991) Efeito do arranjo de plantas no rendimento de grãos, componentes do rendimento, teor de óleo e no controle de plantas daninhas em girassol. Pesquisa Agropecuária Brasileira, 26:1503-1508. 
Silva PRF, Rizzardi MA, Trezzi MM \& Almeida ML (1995) Densidade e arranjo de plantas em girassol. Pesquisa Agropecuária Brasileira, 30:797-810.

Vogt GA, Balbinot Junior AA \& Souza AM (2012) Divergência fenotípica em genótipos de girassol. Revista de Ciências Agroveterinárias, 11:26-34.
Yokomizo E (2003) O combustível do girassol. Crea, 21:18-23.

Zenebon O, Pascuet NS \& Tiglea P (2008) Métodos físico-químicos para análise de alimentos. São Paulo, Instituto Adolfo Luiz. 1020 p. 